\title{
Legal Education and Admission to the Bar
}

\author{
[Extracts from Committee Report to North Carolina Bar Association.
} Alexander B. Andrews, Chairman. Asheville, N. C., June, rg28]

$T^{\mathrm{HE}}$ action of the American Bar Association in 1921 declaring for 1 a standard of legal education based upon (a) a two years' college course and (b) a three years' study of the law in a full-time law school, as a minimum requirement for admission to the bar, is something towards which all members of the profession should work.

Recently there has been compiled a brief statement showing (a) the educational requirements in each of the forty-nine (District of $\mathrm{Co}$ lumbia included) law licensing jurisdictions, and (b) a similar statement of the requirements as to the length of time required for the course of law. These statements are set out in the address of Mr. Silas $H$. Strawn, before the Florida Bar Association, at Jacksonville, Fla., April 8, 1927. ${ }^{1}$

Could these several requirements be grouped on a basis similar to the groupings now used in appraising the values of public school teachers training, on which is based their certificate?

This idea is very clearly set forth in State School Facts (North Carolina Department of Education) dated October 15, 1927, from which we quote the following:

"In order to measure the progress of a school unit in. one phase of school life or compare its standing in this phase with another unit, there must be a unit or standard for expressing this measurement. In this study of measuring the scholastic training of white teachers, a very simple device is used, which is called the scholarship index. The scholarship index indicates the average scholastic training of the teachers of a given unit for a stated year. It is calculated in the following inanner: for every year's training above elementary school a score of 100 points is credited to the teacher, $e$. g., a teacher having successfully completed one year of college is given 500 points which represents 4 years high school, 400 points, and one year college, 100 points. Four years college scores 800 points. Since all certificates are issued on the basis of scholastic credits from institutions, this calculation is made simply by tabulating the certificates held by the teachers employed, assigning the scores to each type of certificate, and for the scholarship index by dividing the total scores by the number of teachers."

Using this same method of valuation, would it be practicable to

1 Reprinted in Aarerican Bar Association Journat, July, 1927, page 384. They are also reprinted in the 1927 Norter Carolina Bar Association ProcerdInGS, pages 74 and 75 . 
take 100 for each year of English ${ }^{2}$ training above the grammar school, that is a value of 400 for a high school graduation and 600 for the completion of two years' college course, and then allow 100 for each year of legal study mininum requirement, as 31 States have the three year course?

The several state mininum requirenients, both preliminary English and legal education, have been assenbled in Table $I$ and are set forth in the second and third columns, while in the fourth and fifth columns are the comparative valuations placed on these requirements, namely, 100 for each year above the grammar grade for English education, with a maxinum of 600 , and 100 for each year of law school study, with a maximum of 300 , making the aggregate maximum of 900 for the highest standard. However, in order to differentiate between states like Illinois, Ohio and New York, who require two years college work prior to beginning the study of law, and states hike Montana and Wisconsin, which require completion of two years of college work before taking bar examination, there has been arbitrarily made a charge of 25 points deducted from those states who can complete their college education in it before taking examination. In the same way the states that require high school graduation before beginning the study of law, are given a valuation of 400 , while those who provide that a high school graduation nuade before taking the bar examination, have 25 points deducted and are valued at 375 .

2 The word "English" is used in this report to designate pre-professional training. [Ed.] 
TABLE I

Minimum Requirements by States and Territories, 1927

\begin{tabular}{|c|c|c|c|c|c|}
\hline States & English & Law & English & Law & Total \\
\hline Jabama.. & \multirow{49}{*}{$\begin{array}{c}\text { None } \\
\text { None } \\
\text { None } \\
\text { None } \\
\text { *Coll. } 2 \\
\text { H.S. } \\
\text { H.S. } \\
\text { *H.S. } \\
\text { None } \\
\text { None } \\
\text { *H.S. } \\
\text { Coll.2 } \\
\text { None } \\
\text { *H.S. } \\
\text { Coll. } 2 \\
\text { *H.S. } \\
\text { *H.S. } \\
\text { *H.S. } \\
\text { H.S. } \\
\text { *(H.S.)2 } \\
\text { H.S. } \\
\text { H.S. } \\
\text { *H.S. } \\
\text { *G.S. } \\
\text { *Coll.2 } \\
\text { *(H.S.) } 3 \\
\text { None } \\
\text { None } \\
\text { H.S. } \\
\text { *H.S. } \\
\text { Coll. } 2 \\
\text { None } \\
\text { None } \\
\text { Coll. } 2 \\
\text { *H.S. } \\
\text { *H.S. } \\
\text { H.S. } \\
\text { H.S. } \\
\text { H.S. } \\
\text { *H.S. } \\
\text { H.S. } \\
\text { None } \\
\text { None } \\
\text { *H.S. } \\
\text { None } \\
\text { H.S. } \\
\text { Coll.2 } \\
\text { *Coll. 2 } \\
\text { None }\end{array}$} & \multirow[t]{2}{*}{$11 / 2$} & & \multirow[t]{2}{*}{150} & \multirow[t]{2}{*}{150} \\
\hline 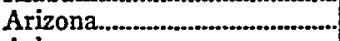 & & & & & \\
\hline Arkansas............................. & & & & & \\
\hline California................. & & 3 & & \multirow{5}{*}{$\begin{array}{l}300 \\
300 \\
300 \\
300 \\
300\end{array}$} & \multirow{5}{*}{$\begin{array}{l}300 \\
875 \\
700 \\
700 \\
675\end{array}$} \\
\hline Colorado................ & & 3 & 575 & & \\
\hline 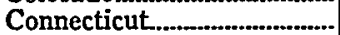 & & 3 & 400 & & \\
\hline Delaware......................... & & 3 & 400 & & \\
\hline District of Columbia. & & 3 & 375 & & \\
\hline 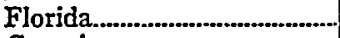 & & & & & 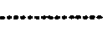 \\
\hline \multicolumn{5}{|c|}{ None } & \\
\hline Idaho & & 3 & 375 & 300 & \multirow{2}{*}{$\begin{array}{l}675 \\
900\end{array}$} \\
\hline 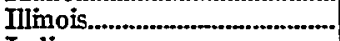 & & 3 & 600 & 300 & \\
\hline \multicolumn{5}{|c|}{$\begin{array}{l}\text { None } \\
\text { *H.S. }\end{array}$} & \\
\hline Iowa....... & & 3 & & 300 & 675 \\
\hline Kansas........................................... & & 3 & 600 & 300 & 900 \\
\hline 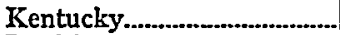 & & 2 & 375 & 200 & 575 \\
\hline 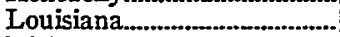 & & 3 & 375 & 300 & 675 \\
\hline 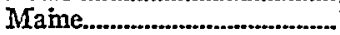 & & 3 & 375 & 300 & 675 \\
\hline 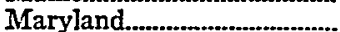 & & 3 & 400 & 300 & 700 \\
\hline setts & & 3 & 175 & 300 & 475 \\
\hline Michi & & 3 & 400 & 300 & 700 \\
\hline a. & & 3 & 400 & 300 & \\
\hline \multirow{2}{*}{\multicolumn{5}{|c|}{$\begin{array}{l}\text { Mississippi........ } \\
\text { Missouri }\end{array}$}} & \\
\hline & & & & & \\
\hline \multirow{2}{*}{\multicolumn{5}{|c|}{$\begin{array}{l}\text { Montana... } \\
\text { Nebraska }\end{array}$}} & \\
\hline \multirow{2}{*}{\multicolumn{5}{|c|}{ 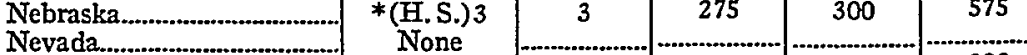 }} & \\
\hline & & & & & \\
\hline \multicolumn{5}{|l|}{ 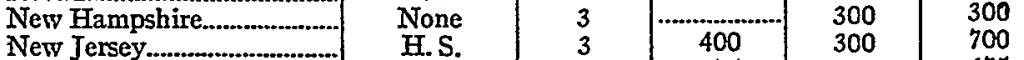 } & \\
\hline New Jersey...................... & & 3 & 400 & 300 & 700 \\
\hline New Mexico........ & & 3 & 375 & 300 & 675 \\
\hline New York. & & 3 & 600 & 300 & 900 \\
\hline & & 2 & ....... & 200 & 200 \\
\hline \multirow{2}{*}{ 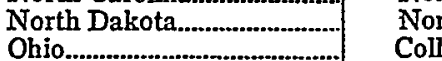 } & & & & & \\
\hline & & 3 & 600 & 300 & 900 \\
\hline \multirow{2}{*}{ 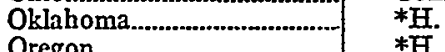 } & & 2 & & & \\
\hline & & 3 & 375 & 300 & 675 \\
\hline & & 3 & 400 & 300 & 700 \\
\hline \multirow{2}{*}{\multicolumn{5}{|c|}{ 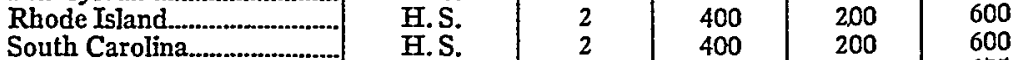 }} & \\
\hline & & 2 & 400 & & 600 \\
\hline \multirow{2}{*}{\multicolumn{5}{|c|}{ 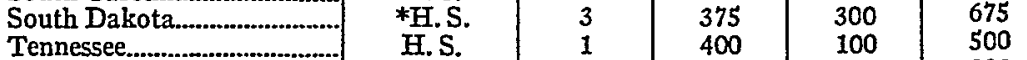 }} & \\
\hline & & 1 & 400 & 100 & 500 \\
\hline \multirow{2}{*}{\multicolumn{5}{|c|}{$\begin{array}{l}\text { Texas................. } \\
\text { Utah }\end{array}$}} & \\
\hline & & 3 & 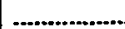 & 300 & \\
\hline Vermont..... & & 3 & 375 & 300 & 675 \\
\hline \multicolumn{5}{|l|}{ Virginia.......................-........... } & \\
\hline Washingto & & 3 & 400 & 300 & 700 \\
\hline nia........................... & & 3 & 600 & 30 & 900 \\
\hline 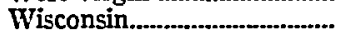 & & 3 & 575 & & 875 \\
\hline 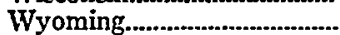 & & 3 & & 300 & 300 \\
\hline
\end{tabular}

*Means "Before Examination." Others are before beginning study of law. (H.S.) means less than high school completion.

Coll. 2 means two years of college coinpleted.

49 states average minimum English Index 278.06.

49 states average mimimum Legal Index 223.47.

By arranging the states according to their rating as set forth in column 5 , we get table No. 2, which is the table of comparative values, and is as follows: 
With this explanation, Table II will be found simply an easy reading:

TABLE II

Comparative Index of Standards

\begin{tabular}{|c|c|c|c|c|c|}
\hline Rank & States & Index & Rank & States & Index \\
\hline 1 & Illinois... & 900 & 26 & Rhode Island........... & 600 \\
\hline 2 & Kansas........ & 900 & 27 & South Carolina............... & 600 \\
\hline 3 & New York. & 900 & 28 & Kentucky....................... & 575 \\
\hline 4 & Ohio.................... & 900 & 29 & 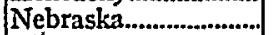 & 575 \\
\hline 5 & West Virginia......... & 900 & 30 & 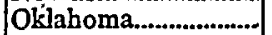 & 575 \\
\hline 6 & Colorado.................. & 875 & 31 & Tennessee...................... & 500 \\
\hline 7 & Wisconsin... & 875 & 32 & Massachusetts......... & 475 \\
\hline 8 & Montana....... & 775 & 33 & 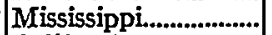 & 375 \\
\hline 9 & Connecticut................. & 700 & 34 & 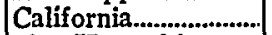 & 300 \\
\hline 10 & Delaware..................... & 300 & 35 & New Hampshire..... & 300 \\
\hline 11 & Maryland. & 700 & 36 & North Dakota............ & 300 \\
\hline 12 & Michigan.... & 700 & 37 & 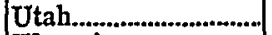 & 300 \\
\hline 13 & Minnesota..... & 700 & 38 & Wyoming........................ & 300 \\
\hline 14 & New Jersey............ & 700 & 39 & North Carolima......... & 200 \\
\hline 15 & Pennsylvania.......... & 700 & 40 & 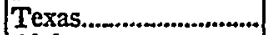 & 200 \\
\hline 16 & 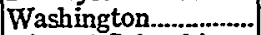 & 700 & 41 & Álabama.............................. & 150 \\
\hline 17 & Dist. of Columbia.... & 675 & 42 & 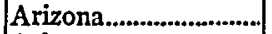 & ........... \\
\hline 18 & 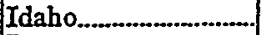 & 675 & 43 & Arkansas......................... & .......... \\
\hline 19 & Iowa............................. & 675 & 44 & 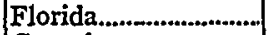 & .......... \\
\hline 20 & Louisiana...................... & 675 & 45 & Georgia.......................... & ........... \\
\hline 21 & Maine............................... & 675 & 46 & 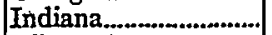 & ........... \\
\hline 22 & New Mexico................. & 675 & 47 & 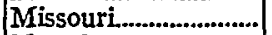 & .......... \\
\hline 23 & 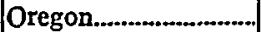 & 675 & 48 & Nevada............................. & .......... \\
\hline 24 & South Dakota............. & 675 & 49 & 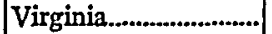 & .......... \\
\hline 25 & Vermont....................... & 675 & & & \\
\hline
\end{tabular}

This shows that the 49 states average among themselves a standard of 511, which is three years of law work plus 2 years of high school work. Or it may be two years of law work plus 3 years of high school work.

It is noticeable that the first 30 average among themselves 720 , while the last 19 average among themselves 178 .

While the above tables are interesting, a more practicable way of classifying these states is by taking the nine divisions used by the U.S. Census office, which groups neighboring states of similar characteristics, and in general a similar population, and then averaging the same. This is Table III, which is as follows: 
TABLE III

States by Geographical Groups

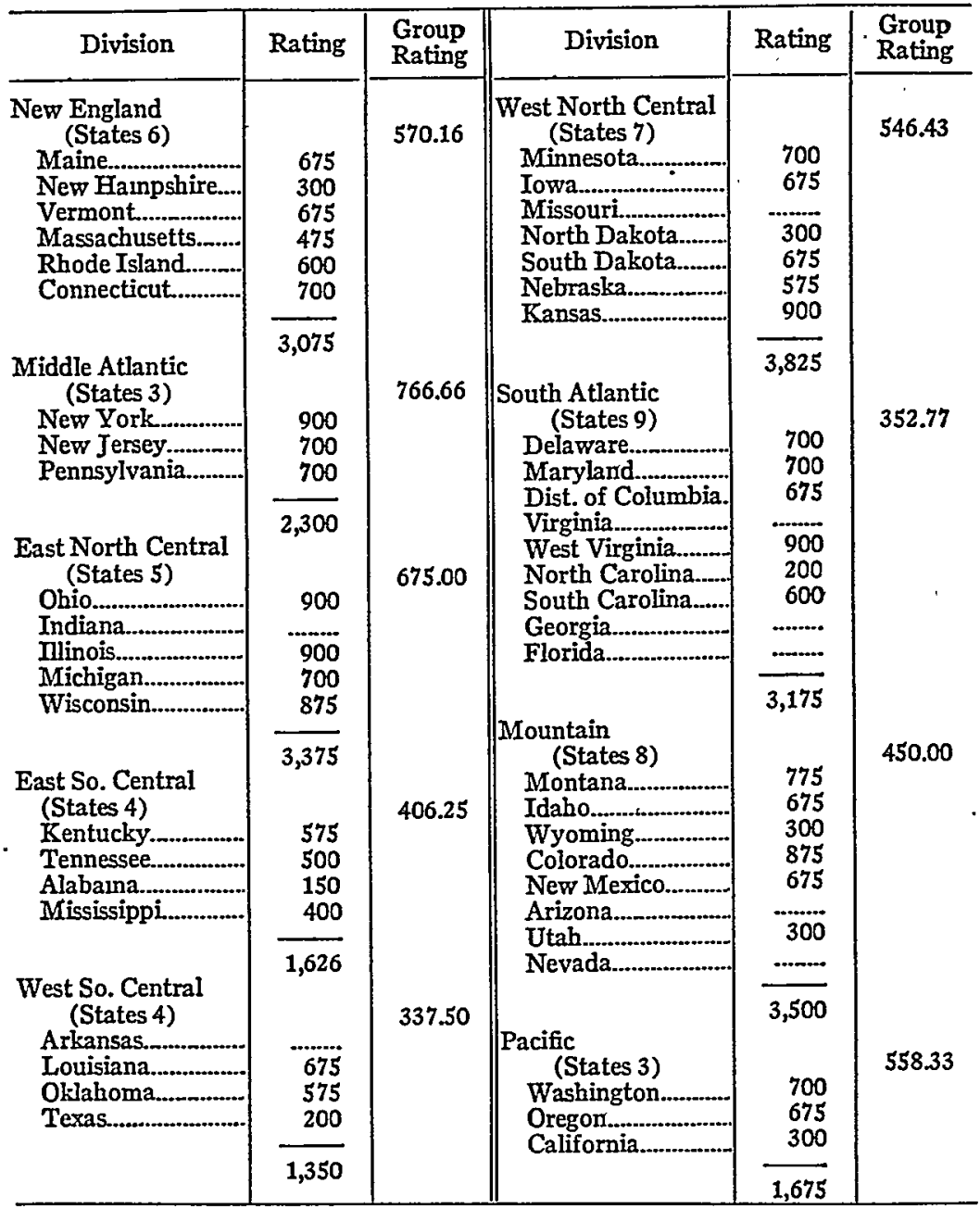

*****

It is interesting to contrast the present requirements of Englisl and legal education as compared with various other professions and occupations to which admission is regulated by statute or by governing board of state examiners.

These may be given as follows:

(1) Doctors (C. S. 6613, page 611) English education required is for college entrance at the University of North Carolina, and medical 
education required of four years of college followed by one and onehalf years service as interne in a recognized hospital. All medical colleges now restrict admission to two years college completion before entering the study of medicine.

(2) Civil Engineering (C. S. 6055-J, page 487). Four years of college work in a recognized college of engineering.

(3) Dentist (C. S. 6631, page 617). English education standard determined by board of examiners and three years course in dental college. As dental colleges only admit those who have completed two years of college work, this is practically two years college required.

(4) Public Accountants (C. S. 7015, page 718). Must be graduate of a high school and work three years under a public accountant.

(5) Osteopaths (C. S. 6702, page 641). High school graduate followed by three years college of Osteopathy.

(6) Chiropractors (C. S. 6715, page 644). High school education followed by three years college of Chiropractic.

(7) Trained Nurses (C. S. 6731, page 648). One year of high school followed by three years professional training at hospital. As standards of nursing in other states require high school graduation before entering on study of nursing, most hospitals in North Carolina accept only high school graduates for training.

(8) Optometrists (C. S. 6691, page 637). High school graduation plus two years in school of Optometry.

(9) Chiropodists (C. S. 6766, page 655). Four years of high school training plus graduation from "legally incorporated school of Chiropody (podiatry) acceptable to the board."

(10) Pharmacist (C. S. 6658, page 523). English education not specified but four years training in Pharmacy including two years attendance in college of Pharmacy.

(11) Public School Teachers. To obtain an Elementary certificate one must now be a high school graduate and have taken two years course in teachers' training.

When we consider the plan used by the State Department of Education in comparing the educational traiming of teachers which is by allowing 100 for each year above the grammar grade, that is, 400 for a high school graduate, and 600 for two years of college work, it is entertaining to take count of how these various professions and occupations, admission to which is regulated by statute or by board, class and grade themselves, which is Table XII and is as follows: 
TABLE XII

Other Requirements in North Carolina

\begin{tabular}{|c|c|c|c|}
\hline Professions & English & Professional & Post Graduate \\
\hline 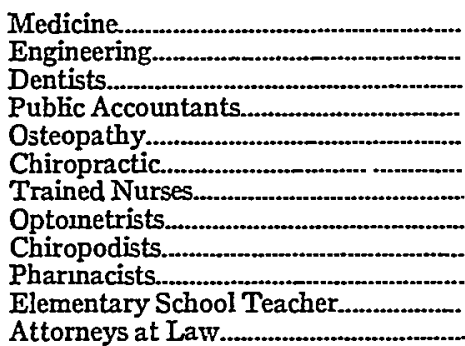 & $\begin{array}{l}\text { Col.2 } \\
\text { H.S. } \\
\text { Col.2 } \\
\text { H.S. } \\
\text { H.S. } \\
\text { H.S. } \\
\text { H.S.1 } \\
\text { H.S. } \\
\text { H.S. } \\
\text { H.S. }\end{array}$ & $\begin{array}{l}4 \text { years } \\
4 \text { years } \\
3 \text { years } \\
3 \text { years } \\
3 \text { years } \\
3 \text { years } \\
3 \text { years } \\
2 \text { years } \\
2 \text { years } \\
4 \text { years } \\
2 \text { years } \\
2 \text { years }\end{array}$ & 18 months \\
\hline
\end{tabular}

By grading these on a basis of 100 for each year of English or professional training required above the grammar school, we get the following gradations, which is Table XIII and is as follows:

TABLE XIII

Index Comparison of North Carolina

\begin{tabular}{|c|c|c|c|c|c|}
\hline Rank & Profession & English & Professional & Post Graduate & Total \\
\hline 1 & Doctors. & 600 & 400 & 150 & 1150 \\
\hline 2 & Dentists.............. & 600 & 300 & $\ldots$ & 900 \\
\hline 3 & Civil Engineers............................ & 400 & 400 & ....... & 800 \\
\hline 4 & Public Accountants................ & 400 & 300 & ........ & 700 \\
\hline 5 & 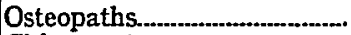 & 400 & 300 & ....... & 700 \\
\hline 6 & 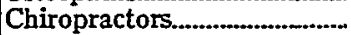 & 400 & 300 & ........ & 700 \\
\hline 7 & Eleinentary School Teachers. & 400 & 200 & $\ldots$ & 600 \\
\hline 8 & Optometrists. & 400 & 200 & $-\ldots-.$. & 600 \\
\hline 9 & 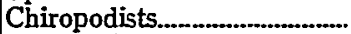 & 400 & 200 & ...... & 600 \\
\hline 10 & 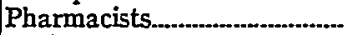 & & 400 & ....... & 400 \\
\hline 11 & 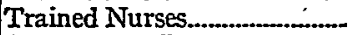 & 100 & 300 & $\ldots . . .$. & 400 \\
\hline 12 & 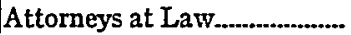 & $\ldots . . .$. & 200 & $\ldots . . .$. & 200 \\
\hline
\end{tabular}

Alexander B. Andrews, Chairman. 